\title{
Long-term effect of crop residues incorporation on yield and soil physical properties under rice - wheat cropping system in calcareous soil
}

\author{
Kamini Kumari ${ }^{1}$, Janardhan Prasad ${ }^{1}$, Ishwar Singh Solanki ${ }^{2}$, Ravish Chaudhary ${ }^{2 *}$ \\ ${ }^{1}$ Department of Soil Science, Rajendra Agricultural University (RAU), Pusa-848 125, Samastipur, Bihar, India. \\ ${ }^{2}$ ICAR - Indian Agricultural Research Institute Regional Station, Pusa-848 125, Samastipur, Bihar, India. \\ *Corresponding author: ravianu1110@gmail.com; ravish@iari.res.in
}

\begin{abstract}
The crop residue and $\mathrm{Zn}$ addition impacts on above ground biomass yield, Zn uptake and physical properties, viz. mean weight diameter (MWD) of water stable aggregates, bulk density (BD) and water holding capacity (WHC) were measured under a rice-wheat system in the $17^{\text {th }}$ and $18^{\text {th }}$ crop cycles. Results indicate that the highest yield in both the crops was recorded in the treatment receiving $10 \mathrm{~kg} \mathrm{Zn} / \mathrm{ha}$ as starter dose $+100 \%$ straw produced by each crop. Long-term application of crop residues along with $\mathrm{Zn}$ increased grain yield. The MWD, BD and WHC of post-harvest soil measured after harvest of the wheat crop varied from 2.80-3.88 mm, 1.27-1.42 $\mathrm{Mgm}^{-3}$ and 33.32-47.53\%, respectively. The treatment with $100 \% \mathrm{CR}$ and $10 \mathrm{~kg} \mathrm{Zn/ha} \mathrm{had} \mathrm{the} \mathrm{high-}$ est level of MWD and WHC, whereas it resulted into the lowest BD. Increasing levels of Zn also influenced the MWD of water stable aggregates, BD and WHC positively. The correlations of WHC and MWD of water stable aggregates with different plant parameters were positive and highly significant, thus, indicating their synergistic relationship, i.e. higher the WHC and MWD of water stable aggregates higher the crop yield and Zn utilization by crops.
\end{abstract}

Keywords: Water stable aggregates, bulk density, water holding capacity, residual effect of Zn, correlation coefficients, multiple regression analysis 


\section{Introduction}

Rice-wheat cropping system is a widely adopted cropping system in north India. This cropping system covers about 24.0 mha in China, India, Pakistan, Nepal and Bangladesh, and zinc ( $\mathrm{Zn})$ deficiency is wide spread in rice-wheat belts of all these countries (Shivay, 2008). The wide scale adoption of this cropping system has increased the agricultural production, but this intensive system over a period of time and nature of crops has set both declining yield trend and deterioration in soil productivity even with optimum use of fertilizers. Hence, for restoration of soil fertility and higher production, there is an urgent need to look forward for another option like, crop residue incorporation in soil.

During last three decades, mineral fertilizers are playing a dominant role in rice based cropping systems. But the doses of fertilizers may be substituted by the incorporation of crop residues in soils. Incorporation of crop residue alters the soil environment, improves the physical properties of soil and influences the microbial population in soil. Land is a shrinking resource for agriculture. The area under agriculture is decreasing and population is increasing day-by-day. Therefore, we will have to produce more with lesser land. We need to produce 50 million tons (Mt) of additional food grains to feed the increasing population in ensuing ten years. The increasing cost of labourers and their decreasing numbers have led to increased use of combine harvesters, especially in the ricewheat cropping system. Due to machine harvesting, a large amount of residue is left in the field which requires proper management like, its incorporation in soil that provides long term good environment for the soil health. Widespread occurrence of $\mathrm{Zn}$ deficiency in soil has been reported in many parts of our country, particularly where high yielding fertilizer responsive crops are being grown intensively.
The calcareous soils of Bihar, occupying a sizeable area, are deficient in $\mathrm{Zn}$ to the extent of $80 \%$ of tested soil samples, and symptoms of $\mathrm{Zn}$ deficiency are frequently observed in many crops (Sakal and Singh, 1979). Zinc is a vital micronutrient for all the plants involved in a wide array of metabolic processes like, carbohydrate, lipid, protein and nucleic acid synthesis and degradation (Sirohi et al., 2015). Major crops affected by zinc deficiency include wheat, rice, maize, cotton and citrus (Rashid and Ryan, 2008). Zinc deficiency is significantly encountered in plants growing in calcareous and sodic soils due to the formation of insoluble zinc carbonate which decreases the availability of this metal (Sirohi et al., 2015). Application of $\mathrm{Zn}$ fertilizer is essential for realizing desirable levels of yield in different crops. For these reasons, application of $\mathrm{Zn}$ fertilizer to various crops has become a common practice during the past 2-3 decades. Longterm application of $\mathrm{Zn}$ and crop residues increased the organic matter content of soil. The combined use of $\mathrm{Zn}$ and crop residues significantly increased crop yield, micronutrient uptake and availability of micronutrients in soils over mineral fertilizer alone (Prasad, 2009). The multiple regression analysis of plant parameters with physical properties of soil was carried out to explain the variations in plant parameters, i.e. grain yield of rice and wheat and $\mathrm{Zn}$ uptake by rice and wheat as influenced by physical properties of soil, viz. bulk density, water holding capacity and mean weight diameter of water stable aggregates.

Organic residue recycling is increasing and becoming an important aspect of environmentally sound sustainable agriculture and organic materials hold a great promise due to their local availability as a source of multiple nutrients and ability to improve soil physical characteristics. Thus, quantification of crop residue with respect to $\mathrm{Zn}$ nutrition under rice-wheat cropping 
system seems to be important in these soils. Thus, the hypothesis of this experiment was that different levels of $\mathrm{Zn}$ and crop residue incorporation (alone and/ or in combination) improve soil physical properties and crop productivity in the calcareous soil of eastern Indo-Gangetic Plains.

\section{Material and Methods}

A field experiment was conducted during 2010-11 and 2011-12 in light textured highly calcareous soil deficient in available $\mathrm{Zn}(0.56 \mathrm{mg} / \mathrm{kg})$ at Research Farm, R.A.U., Pusa, Bihar (India). The experimental soil $(0-15 \mathrm{~cm})$ had $\mathrm{pH}(1: 2) 8.5$, EC $0.36 \mathrm{dS} / \mathrm{m}$, oxidizable organic carbon $0.62 \mathrm{~g} / \mathrm{kg}$, available N 236.1 $\mathrm{kg} / \mathrm{ha}$, available P $19.7 \mathrm{~kg} / \mathrm{ha}$, available K $100.0 \mathrm{~kg}$ / ha, available Zn $0.56 \mathrm{mg} / \mathrm{kg}$, available Fe $15.82 \mathrm{mg} /$ $\mathrm{kg}$, available $\mathrm{Mn} 3.30 \mathrm{mg} / \mathrm{kg}$ and available $\mathrm{Cu} 2.28$ $\mathrm{mg} / \mathrm{kg}$. Four levels of crop residues, viz. no crop residue (CR0), 25\% of straw produced (CR25), 50\% of straw produced (CR50) and $100 \%$ of straw produced (CR100) were applied as treatment in main plots. The treatments were given to each crop during every year. The main plot was divided into 4 sub-plots in which treatments, viz. no $\mathrm{Zn}(\mathrm{Zn} 0), 2.5 \mathrm{~kg} \mathrm{Zn} / \mathrm{ha}(\mathrm{Zn} 2.5)$, $5.0 \mathrm{~kg} \mathrm{Zn} / \mathrm{ha}(\mathrm{Zn} 5.0)$ and $10 \mathrm{~kg} \mathrm{Zn} / \mathrm{ha}(Z n 10.0)$ were superimposed over crop residues levels. These four levels of $\mathrm{Zn}$ were applied only to first crop as a starter dose. The experiment was laid out in a split plot design with three replications and plot size was $(5.0 \mathrm{x}$ 2.0) $\mathrm{m}^{2}$. The recommended doses of NPK (120:60:40) were applied to each crop of rice and wheat as urea, single superphosphate and murate of potash. Half of nitrogen and entire doses of $\mathrm{P}$ and $\mathrm{K}$ were applied at the time of transplanting of rice and sowing of wheat and remaining $\mathrm{N}$ fertilizer was applied in equal splits at tillering and flower initiation stage. Rice and wheat crops were grown continuously under rice - wheat cropping system. Rice cv., Rajshree was grown as $33^{\text {rd }}$ and $35^{\text {th }}$ test crop and wheat cv., HD 2733 was grown as $34^{\text {th }}$ and $36^{\text {th }}$ test crop during the reported years, 2010-11 and 2011-12.

The crop residue in terms of straw production in respective treatment plots was added after the harvest of rice and wheat crop. The crop was allowed to grow till maturity to record grain and straw yields. The plant samples (grain and straw) from rice and wheat plots were collected, processed and washed sequentially in detergent solution ( $0.2 \%$ liquid), $0.01 \mathrm{~N} \mathrm{HCl}$ solution and deionized water, and dried in oven at $700 \mathrm{C}$. Finely grained sample were digested in a di-acid mixture $\left(\mathrm{HNO}_{3}: \mathrm{HClO}_{4}: 3: 1 \mathrm{~V} / \mathrm{V}\right)$ and the diluted and digested samples were analyzed for micronutrient (Zn) using atomic absorption spectrophotometer. The micronutrient uptake by rice and wheat crops in grain and straw was computed. The WHC and BD of the post-harvest soil were determined by Kin box method (Jackson, 1978) and MWD of water stable aggregates was determined following Yoder (1936).

The data of two years were analyzed statistically at a significance level of $\mathrm{P}<0.05$ through Statistical Analysis System (SAS) version 9.3 (32) by using one-way ANOVA (analysis of variance) to determine the least significant difference, and the differences in means were evaluated by Tukey's test to separate the treatment means and to compare the results.

\section{Results}

\subsection{Pooled yield of $33^{\text {rd }}$ and $35^{\text {th }}$ rice crops}

The residual effects of graded levels of residual starter $\mathrm{Zn}$, continuous incorporation of graded levels of crop residue of previous crop (wheat) on grain and straw yield of rice ( $33^{\text {rd }}$ and $35^{\text {th }}$ crops) and their interaction under rice-wheat cropping system were found statistically significant (Table 1). The grain and straw yields of rice varied from 3.33-4.52 and 5.47-7.22 t/ha, re- 


\subsection{Pooled yield of $34^{\text {th }}$ and $36^{\text {th }}$ wheat crops}

The residual effects of graded levels of residual starter $\mathrm{Zn}$, continuous incorporation of graded levels of crop residues of previous crop (rice) on grain and straw yield of wheat ( $34^{\text {th }}$ and $36^{\text {th }}$ crops) and their interaction under rice-wheat cropping system were statisti- cally significant (Table 2). The grain and straw yields varied from 3.27-4.45 and 4.76-6.51 t/ha, respectively. The highest grain (44.5 t/ha) and straw (6.51 t/ha) yields were observed in the treatment receiving $100 \%$ crop residue incorporation along with residual starter application of $10 \mathrm{~kg} \mathrm{Zn/ha}$.

Table 2. Effect of residual starter zinc and crop residue incorporation on grain and straw yield ( $\mathrm{t} / \mathrm{ha}$ ) of wheat.

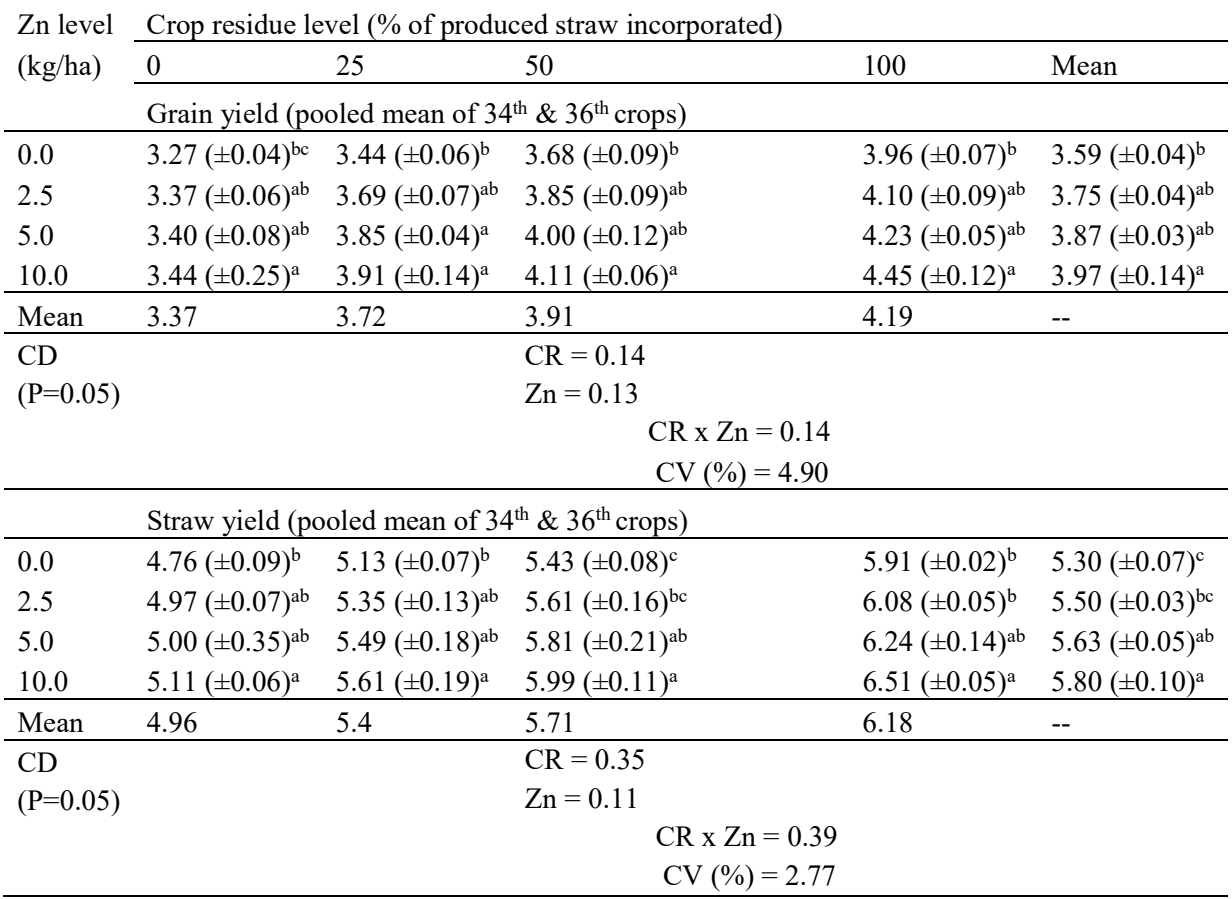

Data were subjected to one-way ANOVA analysis and differences among treatments were determined by Tukey's test. Different letters mean statistical differences at $p<0.05$. 


\subsection{Zinc uptake by rice crop}

The range of variation observed in $Z n$ uptake by $33^{\text {rd }}$ and $35^{\text {th }}$ rice crop due to different levels of $\mathrm{Zn}$ and crop residue incorporation was 168-379 $\mathrm{g} / \mathrm{ha}$ (Table 3; Figure 1). The levels of $\mathrm{Zn}$ and crop residues and their interactions significantly influenced average $\mathrm{Zn}$ uptake in $33^{\text {rd }}$ and $35^{\text {th }}$ rice crops. The $\mathrm{Zn}$ uptake increased significantly with increasing levels of residual $\mathrm{Zn}$ and crop residues incorporation from 222-309 and 200-327 g/ha, respectively.

Table 3. Effect of residual starter zinc and crop residue incorporation on zinc uptake $(\mathrm{g} / \mathrm{ha})$ by rice and wheat.

\begin{tabular}{|c|c|c|c|c|c|}
\hline $\begin{array}{l}\text { Zn } \\
\text { level }\end{array}$ & Crop residue 1 & evel (\% of prod & ced straw inc & rporated) & \\
\hline (kg/ha) & 0 & 25 & 50 & 100 & Mean \\
\hline & Rice (pooled $\mathrm{n}$ & nean of $33^{\text {rd }} \& 3$ & $\left.5^{\text {th }} \mathrm{crops}\right)$ & & \\
\hline 0.0 & $168( \pm 4.61)^{\mathrm{d}}$ & $210( \pm 2.89)^{\mathrm{d}}$ & $232( \pm 2.31)^{\mathrm{c}}$ & $278( \pm 2.89)^{\mathrm{c}}$ & $222( \pm 3.18)^{d}$ \\
\hline 2.5 & $189( \pm 2.31)^{\mathrm{c}}$ & $233( \pm 1.44)^{\mathrm{c}}$ & $264( \pm 1.73)^{\mathrm{b}}$ & $318( \pm 10.31)^{b}$ & $251( \pm 3.12)^{\mathrm{c}}$ \\
\hline 5.0 & $210( \pm 3.46)^{b}$ & $267( \pm 5.19)^{b}$ & $283( \pm 4.04)^{\mathrm{b}}$ & $334( \pm 5.19)^{b}$ & $274( \pm 4.22)^{b}$ \\
\hline 10.0 & $232( \pm 2.31)^{\mathrm{a}}$ & $304( \pm 4.04)^{\mathrm{a}}$ & $319( \pm 5.19)^{\mathrm{a}}$ & $379( \pm 4.62)^{\mathrm{a}}$ & $309( \pm 5.19)^{\mathrm{a}}$ \\
\hline Mean & 200 & 254 & 275 & 327 & -- \\
\hline CD & $\mathrm{CR}=14$ & & & & \\
\hline & $\mathrm{Zn}=12$ & & & & \\
\hline & $\mathrm{CR} \times \mathrm{Zn}=\mathrm{NS}$ & & & & \\
\hline & $\mathrm{CV}(\%)=6.60$ & & & & \\
\hline & Wheat (poolec & mean of $34^{\text {th }} \&$ & $36^{\text {th }}$ crops) & & \\
\hline 0.0 & $178( \pm 2.89)^{\mathrm{c}}$ & $207( \pm 4.04)^{\mathrm{c}}$ & $234( \pm 4.04)^{d}$ & $272( \pm 7.50)^{d}$ & $223( \pm 4.62)^{d}$ \\
\hline 2.5 & $192( \pm 4.62)^{b}$ & $232( \pm 3.46)^{b}$ & $262( \pm 4.62)^{\mathrm{c}}$ & $310( \pm 5.19)^{\mathrm{c}}$ & $249( \pm 4.62)^{\mathrm{c}}$ \\
\hline 5.0 & $203( \pm 1.73)^{\mathrm{ab}}$ & $252( \pm 8.08)^{\mathrm{ab}}$ & $294( \pm 6.35)^{b}$ & $341( \pm 4.62)^{\mathrm{b}}$ & $272( \pm 5.19)^{b}$ \\
\hline 10.0 & $216( \pm 4.04)^{\mathrm{a}}$ & $269( \pm 6.35)^{\mathrm{a}}$ & $319( \pm 5.19)^{\mathrm{a}}$ & $392( \pm 9.81)^{\mathrm{a}}$ & $299( \pm 4.04)^{\mathrm{a}}$ \\
\hline Mean & 197 & 240 & 277 & 329 & -- \\
\hline & $\mathrm{CR}=16$ & & & & \\
\hline$(\mathrm{P}=$ & $\mathrm{Zn}=12$ & & & & \\
\hline & & & $\mathrm{CR} \times \mathrm{Zn}=$ & & \\
\hline & & & $\mathrm{CV}(\%)=$ & & \\
\hline
\end{tabular}

Data were subjected to one-way ANOVA analysis and differences among treatments were determined by Tukey's test. Different letters mean statistical differences at $p<0.05$. 


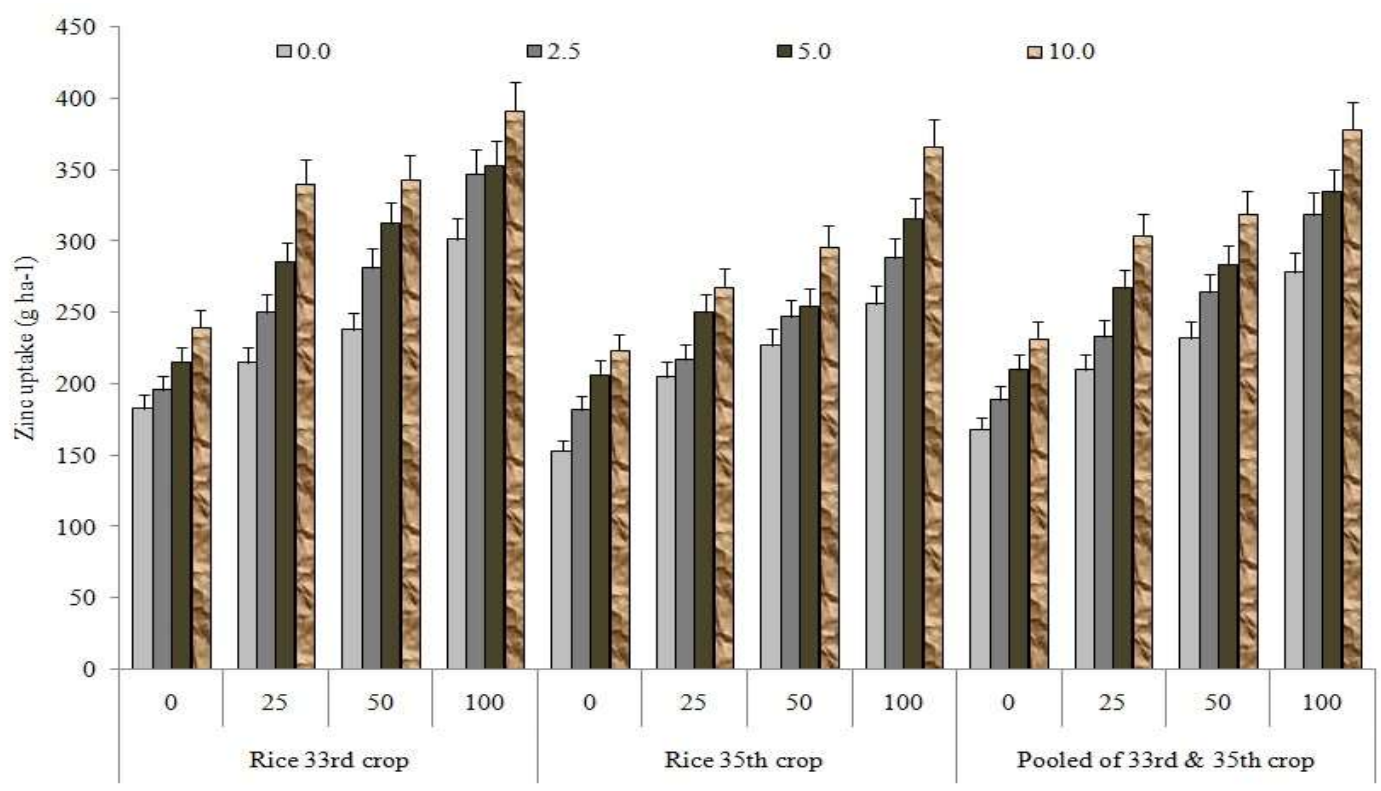

Figure 1. Effect of zinc and crop residue (CR) levels on zinc uptake by rice $\left(33^{\text {rd }} \& 35^{\text {th }} \mathrm{crop}\right)$. Error bars represent Mean \pm S.D of three different experiments

\subsection{Zinc uptake by wheat crop}

The range of variation observed in $\mathrm{Zn}$ uptake by $34^{\text {rd }}$ and $36^{\text {th }}$ wheat crop due to different levels of $\mathrm{Zn}$ and crop residue incorporation was 178-392 g/ha (Table 3; Figure 2). Increasing doses of crop residues incorpo- ration significantly enhanced total $\mathrm{Zn}$ uptake by wheat crop from 197-329 $\mathrm{g} / \mathrm{ha}$ and it might be due to addition of $\mathrm{Zn}$ by previous crop residues of $33^{\text {rd }}$ and $35^{\text {th }}$ rice crop and similarly, increasing doses of $\mathrm{Zn}$ significantly increased the total $\mathrm{Zn}$ uptake by wheat crop from 223-299 g/ha. 


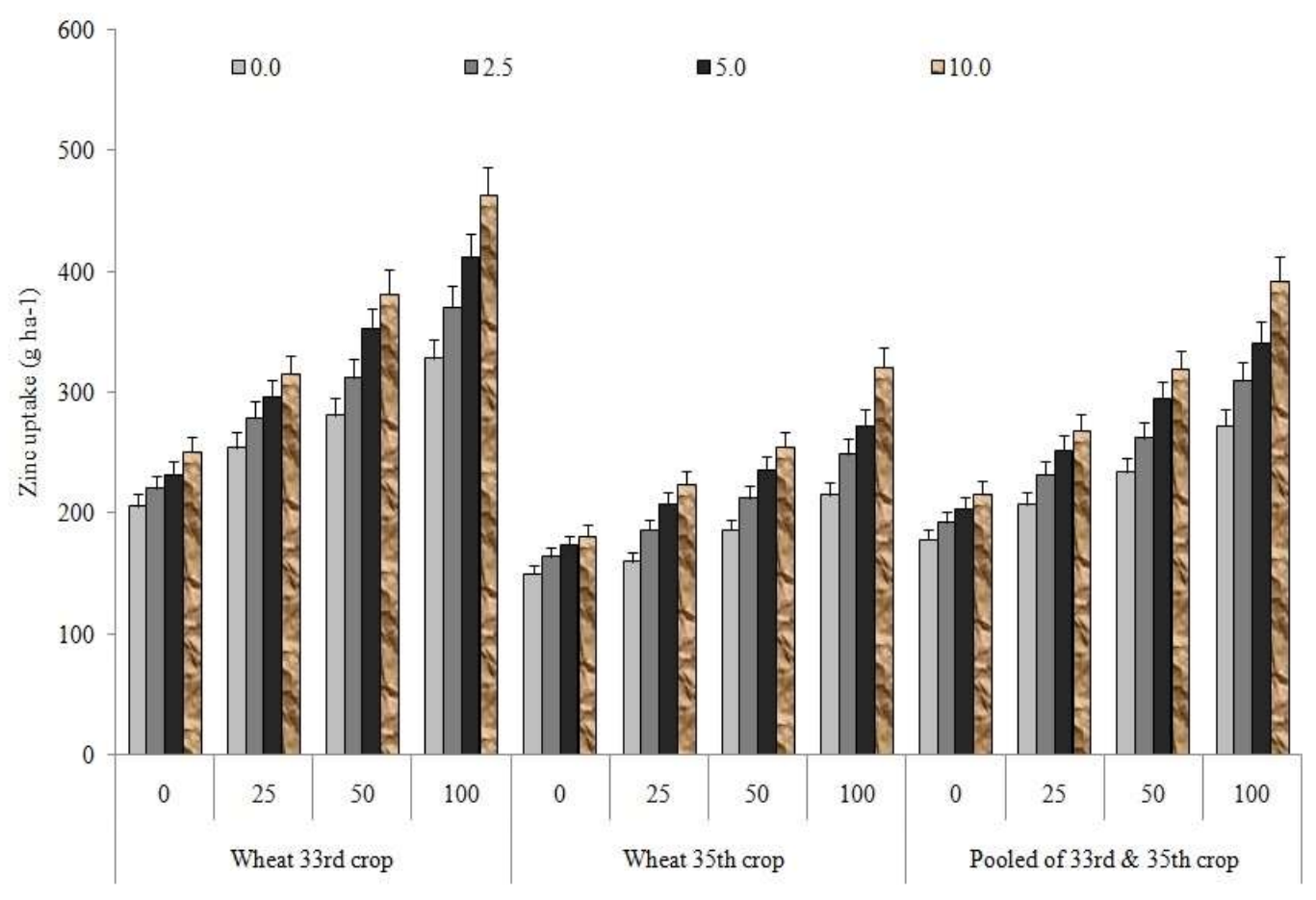

Figure 2. Effect of zinc and crop residue (CR) levels on zinc uptake by wheat ( $34^{\text {th }} \& 36^{\text {th }}$ crop). Error bars represent Mean \pm S.D of three different experiments.

\subsection{Physical properties of soil}

3.5.1. Mean weight diameter (MWD)of water stable aggregates

Data on MWD of post-harvest soil of wheat $\left(36^{\text {th }}\right)$ crop clearly showed that MWD varied significantly both due to crop residues and residual starter $\mathrm{Zn}$ treatments (Table 4). The MWD measured after harvest of wheat crop varied from $2.80-3.88 \mathrm{~mm}$ in crop residue treatments. Increasing levels of $\mathrm{Zn}$ significantly influenced the MWD from 3.29-3.42 mm.

\subsubsection{Bulk Density (BD)}

The BD of post-harvest soil after wheat crop ( $18^{\text {th }}$ rotation) as influenced by different treatments of crop residues and residual starter $\mathrm{Zn}$ significantly and favourably decreased from $1.43-1.25 \mathrm{mg} / \mathrm{m}^{3}$ (Table 4). The BD due to application of increasing residual starter $\mathrm{Zn}$ and crop residue incorporation varied from 1.37-1.34 and 1.42-1.27 mg/m $\mathrm{m}^{3}$. Thus, BD decreased significantly with increasing levels of residual starter $\mathrm{Zn}$ from $0-2.5 \mathrm{~kg} / \mathrm{ha}$ as well as due to levels of crop residue incorporation from $0-100 \%$. 
Table 4. Effect of residual starter zinc and crop residue incorporation on physical properties of post-harvest soil of wheat $\left(36^{\text {th }}\right)$ crop.

\begin{tabular}{|c|c|c|c|c|c|c|c|c|c|c|c|c|c|c|c|}
\hline \multirow{3}{*}{$\begin{array}{l}\mathrm{Zn} \text { level } \\
(\mathrm{kg} / \mathrm{ha})\end{array}$} & \multicolumn{15}{|c|}{ Crop residue level (\% of straw produced ) } \\
\hline & 0 & 25 & 50 & 100 & Mean & 0 & 25 & 50 & 100 & Mean & 0 & 25 & 50 & 100 & Mean \\
\hline & \multicolumn{5}{|c|}{ MWD of water stable aggregates $(\mathrm{mm})$} & \multicolumn{5}{|c|}{$\mathrm{BD}(\mathrm{mg} / \mathrm{m} 3)$} & \multicolumn{5}{|c|}{ WHC (\%) } \\
\hline $\begin{array}{l}0.0 \\
2.5 \\
5.0 \\
10.0\end{array}$ & $\begin{array}{l}2.77 \\
( \pm 0.16)^{\mathrm{b}} \\
2.80 \\
( \pm 0.23)^{\mathrm{ab}} \\
2.81 \\
( \pm 0.05)^{\mathrm{a}} \\
2.83 \\
( \pm 0.03)^{\mathrm{a}}\end{array}$ & $\begin{array}{l}3.17 \\
( \pm 0.09)^{\mathrm{bc}} \\
3.30 \\
( \pm 0.09)^{\mathrm{b}} \\
3.37 \\
( \pm 0.04)^{\mathrm{ab}} \\
3.43 \\
( \pm 0.02)^{\mathrm{a}}\end{array}$ & $\begin{array}{l}3.37 \\
( \pm 0.06)^{\mathrm{ab}} \\
3.38 \\
( \pm 0.04)^{\mathrm{ab}} \\
3.40 \\
( \pm 0.14)^{\mathrm{a}} \\
3.47 \\
( \pm 0.08)^{\mathrm{a}}\end{array}$ & $\begin{array}{l}3.83 \\
( \pm 0.08)^{\mathrm{b}} \\
3.85 \\
( \pm 0.06)^{\mathrm{b}} \\
3.87 \\
( \pm 0.05)^{\mathrm{ab}} \\
3.97 \\
( \pm 0.08)^{\mathrm{a}}\end{array}$ & $\begin{array}{l}3.29 \\
( \pm 0.05)^{\mathrm{b}} \\
3.32 \\
( \pm 0.01)^{\mathrm{b}} \\
3.37 \\
( \pm 0.05)^{\mathrm{ab}} \\
3.42 \\
( \pm 0.04)^{\mathrm{a}}\end{array}$ & $\begin{array}{l}1.43 \\
( \pm 0.06)^{\mathrm{a}} \\
1.43 \\
( \pm 0.17)^{\mathrm{a}} \\
1.42 \\
( \pm 0.29)^{\mathrm{a}} \\
1.41 \\
( \pm 0.46)^{\mathrm{ab}}\end{array}$ & $\begin{array}{l}1.38 \\
( \pm 0.06)^{\mathrm{a}} \\
1.37 \\
( \pm 0.05)^{\mathrm{a}} \\
1.37 \\
( \pm 0.04)^{\mathrm{a}} \\
1.36 \\
( \pm 0.03)^{\mathrm{ab}}\end{array}$ & $\begin{array}{l}1.35 \\
( \pm 0.03)^{\mathrm{a}} \\
1.34 \\
( \pm 0.02)^{\mathrm{a}} \\
1.33 \\
( \pm 0.04)^{\mathrm{ab}} \\
1.33 \\
( \pm 0.04)^{\mathrm{ab}}\end{array}$ & $\begin{array}{l}1.30 \\
( \pm 0.04)^{\mathrm{a}} \\
1.27 \\
( \pm 0.04)^{\mathrm{ab}} \\
1.26 \\
( \pm 0.03)^{\mathrm{ab}} \\
1.25 \\
( \pm 0.02)^{\mathrm{b}}\end{array}$ & $\begin{array}{l}1.37 \\
( \pm 0.05)^{\mathrm{a}} \\
1.35 \\
( \pm 0.01)^{\mathrm{ab}} \\
1.35 \\
( \pm 0.02)^{\mathrm{ab}} \\
1.34 \\
( \pm 0.02)^{\mathrm{ab}}\end{array}$ & $\begin{array}{l}32.92 \\
( \pm 0.46)^{\mathrm{b}} \\
33.00 \\
( \pm 0.25)^{\mathrm{b}} \\
33.37 \\
( \pm 0.17)^{\mathrm{ab}} \\
33.98 \\
( \pm 0.28)^{\mathrm{a}}\end{array}$ & $\begin{array}{l}43.66 \\
( \pm 0.13)^{\mathrm{b}} \\
44.40 \\
( \pm 0.23)^{\mathrm{ab}} \\
44.55 \\
( \pm 0.29)^{\mathrm{ab}} \\
44.80 \\
( \pm 0.14)^{\mathrm{a}}\end{array}$ & $\begin{array}{l}44.62 \\
( \pm 0.21)^{\mathrm{b}} \\
44.25 \\
( \pm 0.14)^{\mathrm{bc}} \\
44.27 \\
( \pm 0.06)^{\mathrm{bc}} \\
46.80 \\
( \pm 0.17)^{\mathrm{a}}\end{array}$ & $\begin{array}{l}46.92 \\
( \pm 0.09)^{\mathrm{b}} \\
47.02 \\
( \pm 0.16)^{\mathrm{b}} \\
47.90 \\
( \pm 0.17)^{\mathrm{a}} \\
48.28 \\
( \pm 0.16)^{\mathrm{a}}\end{array}$ & $\begin{array}{l}42.03 \\
( \pm 0.23)^{\mathrm{b}} \\
42.17 \\
( \pm 0.19)^{\mathrm{b}} \\
42.52 \\
( \pm 0.17)^{\mathrm{b}} \\
43.47 \\
( \pm 0.19)^{\mathrm{a}}\end{array}$ \\
\hline Mean & 2.8 & 3.32 & 3.4 & 3.88 & - & 1.42 & 1.37 & 1.34 & 1.27 & - & 33.32 & 44.35 & 44.98 & 47.53 & - \\
\hline \multirow{4}{*}{$\begin{array}{l}\text { CD } \\
(\mathrm{P}=0.05)\end{array}$} & \multicolumn{2}{|c|}{$\mathrm{CR}=$} & 0.06 & & & & & 0.02 & & & & & 0.15 & & \\
\hline & \multicolumn{2}{|c|}{$\mathrm{Zn}=$} & 0.04 & & & & & 0.01 & & & & & 0.12 & & \\
\hline & \multicolumn{2}{|l|}{$\mathrm{CR} \times \mathrm{Zn}=$} & 0.13 & & & & & 0.04 & & & & & NS & & \\
\hline & $\mathrm{CV}(\%)=$ & & 2.2 & & & & & 2.45 & & & & & 0.43 & & \\
\hline
\end{tabular}

Data were subjected to one-way ANOVA analysis and differences among treatments were determined by Tukey's test. Different letters mean statistical differences at $p<0.05$.

\subsubsection{Water Holding Capacity (WHC)}

Long term effect of graded doses of residual starter $\mathrm{Zn}$ and crop residues either alone or in combination on WHC of the soil (Table 4) showed increase in WHC with increasing levels of residual starter $\mathrm{Zn}$ and crop residue incorporation (32.92-48.28\%). Minimum WHC (32.92\%) was recorded in the plot receiving no $\mathrm{Zn}$ and crop residue, whereas maximum WHC was noted in the plot receiving $10 \mathrm{~kg} \mathrm{Zn}$ and $100 \%$ of crop residue (48.28\%).

The increase in WHC due to increasing levels of $\mathrm{Zn}$ and crop residue incorporation varied from 42.03$43.47 \%$ and $33.32-47.53 \%$, respectively.
3.5.4. Correlation studies between different soil physical properties and plant parameters

The correlation coefficients among different plant parameters (pooled of two years), viz. grain yield of rice (GYR) and wheat (GYW), total Zn uptake by rice (ZnUR) and wheat (ZnUW) and soil physical properties, viz. BD, WHC and MWD computed (Table 5) showed that $\mathrm{BD}$ was highly significantly and negatively correlated with all the plant parameters, whereas WHC and MWD were highly significantly and positively correlated with all the plant parameters indicating their synergistic relationship, except the correlation between MWD and zinc uptake by wheat which was observed as highly significant and negative. 
Table 5. Correlation coefficients among different soil properties and plant parameters.

\begin{tabular}{|c|c|c|c|c|c|}
\hline \multirow{2}{*}{\multicolumn{2}{|c|}{ Soil property }} & \multicolumn{4}{|c|}{ Plant parameter } \\
\hline & & GYR & GYW & ZnUR & ZnUW \\
\hline $\mathrm{BD}$ & & $-0.914 * *$ & $-0.939 * *$ & $-0.900 * *$ & $-0.927^{*}$ \\
\hline WHC & & $0.800^{* *}$ & $0.859 * *$ & $0.799 * *$ & $0.787 * *$ \\
\hline $\begin{array}{l}\text { MWD } \\
\text { aggregates }\end{array}$ & of & $0.882 * *$ & $0.931 * *$ & $0.883 * *$ & $-0.885 * *$ \\
\hline
\end{tabular}

*Significant at $\mathrm{P}=0.05$ lev**Significant at $\mathrm{P}=0.01$ level

3.5.5. Multiple regression studies of soil physical properties with plant parameters

Step down multiple regression analysis of plant parameters with physical properties of soil was carried out to explain the variations in grain yield of rice (Y1) and wheat (Y2) and zinc uptake by rice (Y3) and wheat (Y4) as influenced by physical properties of soil, viz. BD, WHC and MWD of water stable aggregates (Table 6). The least important soil physical factor was discarded step-by-step on the basis of ' $t$ ' value in previous equation. The regression equation explained $83.9 \%$ variations in grain yield of rice due to combined effect of soil physical properties like, $\mathrm{BD}, \mathrm{WHC}$ and MWD. However, the individual effects of all the independent variables were observed to be non-significant. Elimination of least important factors one-by-one decreased the prediction value from 83.9 to $83.5 \%$ and the effect of BD was found significant. Further, deletion of MWD from the regression equation increased the prediction value to the extent of 0.7 $\%$; the BD was found significant and considered dominant factor with regard to grain yield of rice. Standard regression coefficients (given in parentheses in Table 6) indicated the relative importance of X-factors within the regression equation to explain the variation in Y-factor. In the present investigation, equation ' $b$ ' was more appropriate. The change in bulk density was relatively more important than MWD in explaining the variation in grain yield of rice.

Table 6. Step down multiple regression analysis of plant parameters with physical properties of soil.

\begin{tabular}{|c|c|c|c|}
\hline Y factor & Regression analysis & $\mathrm{R}^{2}$ & Adj. $R^{2}$ \\
\hline \multirow[t]{3}{*}{ Grain yield of rice $\left(\mathrm{Y}_{1}\right)$} & (a) $149.86-74.718(-1.251) \mathrm{BD}+0.112(0.182) \mathrm{WHC}-4.438(-0.509) \mathrm{MWD}$ & $0.839^{* *}$ & 0.798 \\
\hline & (b) $35.98-67.221(-1.126) \mathrm{BD}^{*}-1.903(-0.218) \mathrm{MWD}$ & $0.835^{* *}$ & 0.809 \\
\hline & (c) $112.42-54.49 *(-0.92) \mathrm{BD}$ & $0.842^{* *}$ & 0.82 \\
\hline \multirow[t]{3}{*}{ Grain yield of wheat $\left(\mathrm{Y}_{2}\right)$} & (a) $91.39-43.91(-0.75) \mathrm{BD}+0.9(0.16) \mathrm{WHC}+0.58(0.07) \mathrm{MWD}$ & $0.889^{* *}$ & 0.861 \\
\hline & (b) $96.50 * *-46.67 *(-0.79) \mathrm{BD}+0.10(0.18) \mathrm{WHC}$ & $0.889^{* *}$ & 0.872 \\
\hline & (c) $112.88 * *-55.51 *(-0.94) \mathrm{BD}$ & $0.882 * *$ & 0.873 \\
\hline \multirow[t]{3}{*}{ Rice $\mathrm{Zn}$ uptake $\left(\mathrm{Y}_{3}\right)$} & (a) $1359.96-833.24(-0.85) \mathrm{BD}+0.60(0.06) \mathrm{WHC}+0.96(0.01) \mathrm{MWD}$ & $0.812^{* *}$ & 0.765 \\
\hline & (b) $1368.47-837.84 *(-0.85) \mathrm{BD}+0.63(0.07) \mathrm{WHC}$ & $0.810^{* *}$ & 0.783 \\
\hline & (c) $1466.19-890.62 * *(-900) \mathrm{BD}$ & $0.811^{* *}$ & 0.797 \\
\hline \multirow[t]{3}{*}{ Wheat $\mathrm{Zn}$ uptake $\left(\mathrm{Y}_{4}\right)$} & (a) $2358.02 *-1386.65(-1.38) \mathrm{BD}+0.92(0.09) \mathrm{WHC}-78.84 \quad(-0.53) \mathrm{MWD}$ & $0.867^{* *}$ & 0.834 \\
\hline & (b) $2244.30 *-1325.20 *(-1.311) \mathrm{BD}-58.06(-0.39) \mathrm{MWD}$ & $0.866^{* *}$ & 0.845 \\
\hline & (c) $1525.51 * *-936.88(-0.93)^{* *} \mathrm{BD}$ & $0.859^{* *}$ & 0.849 \\
\hline
\end{tabular}

Note: Values in parentheses indicate standard regression coefficients 
The variation in grain yield of wheat was attempted to be explained with the variation in soil physical properties through regression equations. When all the above soil physical parameters were considered together in the regression equation, the predication value was $88.9 \%$ with non-significant effects of $\mathrm{BD}$, WHC and MWD. Elimination of MWD and WHC from the regression equation suggested that the decrease in prediction value was about $0.7 \%$ (equation c). The standard regression coefficient values suggested that the effect of BD was most important in explaining the variations in yield of wheat.

Variations in $\mathrm{Zn}$ uptake by rice were tried to be explained through the variations in $\mathrm{BD}, \mathrm{WHC}$ and MWD of post-harvest soil with the help of regression equations. It was observed that as high as $81.2 \%$ variation in total $\mathrm{Zn}$ uptake by rice could be explained through all the three factors, among which the variation through BD was $81.1 \%$ in total Zn uptake up by difference of $0.1 \%$ variation over previous equation. As high as $86.7 \%$ variation in $\mathrm{Zn}$ uptake by wheat could be explained through the variations in soil physical parameters (BD, WHC and MWD), among which the variation through BD was $85.9 \%$ in total $\mathrm{Zn}$ uptake down by difference of $0.8 \%$ variation over previous equations.

\section{Discussion}

Grain and straw yields of rice increased significantly with increasing levels of crop residues from 3.50-4.26 and 5.92-6.82 t/ha, respectively. The increases in grain and straw yields were significant between 0 and $50 \%$, and 25 and $100 \%$ crop residue levels. The increase in grain and straw yields of rice due to increase in levels of crop residues incorporation might be due to the addition of nutrients through crop residue incorporation or increase in availability of nutrients by complexing properties of crop residues. In plots receiving no crop residues, the yields of rice grain at different levels of starter $\mathrm{Zn}$ application (except first and second) were found at par which indicated that residual effects of $\mathrm{Zn}$ application were very low which increased the yield but not up to the significant level. Grain and straw yields at first and third level, and second and forth levels either of $\mathrm{Zn}$ or crop residues incorporation were found significant which indicated that there was an interaction of residual effect of $\mathrm{Zn}$ and incorporation of crop residues on grain and straw yields of rice (Prasad et al., 2010; Rathod et al., 2012).

The grain and straw yields of wheat increased significantly with increasing levels of $\mathrm{Zn}$ application in pooled data of $34^{\text {th }}$ and $36^{\text {th }}$ wheat crop. The $\mathrm{Zn}$ treated plots at higher levels were significantly superior to the control plot. The pooled mean of grain and straw yields of $34^{\text {th }}$ and $36^{\text {th }}$ crops as influenced by residual starter $\mathrm{Zn}$ varied from 3.59-3.97 and 5.30-58.0 t/ha, respectively (Table 2). Similarly, grain and straw yields of wheat increased significantly with increasing levels of crop residues from 3.37-4.19 t/ha and 4.96-6.18 t/ ha, respectively. The retention of crop residues significantly enhanced the wheat grain and straw yield (Mohammad et al., 2012). The interaction of crop residue and $\mathrm{Zn}$ of pooled data were observed to be significant (Prasad et al., 2010; Rathod et al., 2012).

The significant increase in $\mathrm{Zn}$ uptake by rice crop might be due to the addition of $\mathrm{Zn}$ by previous crop residues of wheat ( $32^{\text {nd }}$ and $34^{\text {th }}$ crops). Such increase in $\mathrm{Zn}$ uptake by rice crop might be due to better utilization of applied as well as native $\mathrm{Zn}$. Crop residues incorporation or decomposition might have increased the $\mathrm{Zn}$ use-efficiency of applied $\mathrm{Zn}$ and might have partly dissolved the comparatively insoluble form of $\mathrm{Zn}$ by the decomposition products of organic matter (Prasad et al., 2009). The interaction effect of $\mathrm{Zn}$ and crop residue was found non-significant. The crop residues after decomposition produced several organic compounds, including humic and fulvic acids and polysaccharides 
which form stable complexes with native zinc. These zinc complexes increased solubility and availability of zinc to wheat crop (Prasad et al., 2010).

Data on MWD of post-harvest soil of wheat $\left(36^{\text {th) }} \mathrm{crop}\right.$ clearly showed that MWD varied significantly both due to crop residues and residual starter $\mathrm{Zn}$ treatments. Increasing levels of $\mathrm{Zn}$ significantly influenced the MWD from 3.29-3.42 mm. These data clearly showed significant improvement in soil aggregation with addition of crop residue suggesting direct influence of crop residue on soil aggregation (Bandyopadhyay et al., 2010; Neelam et al., 2010; Wang et al., 2012). The stability and durability of soil pore structures depend on the degree of aggregation and these pore structures govern retention and movement of water, diffusion of gases, growth and development of roots in the soil. The greater influence of crop residue on MWD may be due to the result of enrichment of organic matter content, as evidenced by higher organic carbon content, which acted as a binding agent for soil properties (Ghildyal and Gupta, 1991).

The BD of post-harvest soil significantly decreased after wheat crop (18 ${ }^{\text {th }}$ rotation). Reduction in BD might be due to the reason that the treatments receiving crop residue maintained higher organic carbon content which resulted in better aggregation and porosity. Similarly, addition of $\mathrm{Zn}$ in sub-plot treatments improved organic carbon content as compared to control and improved aggregation and porosity of the soil (Pandey, 2012). Long term effect of graded doses of residual with WHC of the soil showed increase in WHC. Increase in WHC of soil may be explained in the light of the fact that increasing $\mathrm{Zn}$ levels and crop residues result in the proliferation of roots which added more organic matter to the soil (Walia et al., 2010; Prasad et al., 2010). The correlation coefficients among different plant parameters revealed that increase in status of $\mathrm{Zn}$ and organic carbon as a result of continuous crop residue incorporation alone or along with starter dose of
$\mathrm{Zn}$ got reflected in the increased yield of crops. This suggested that incorporation of crop residue not only increased the crop yield and $\mathrm{Zn}$ utilization by crops but also maintained the soil health leading to sustainable crop production (Kumari, 2003; Kumar, 2006).

\section{Conclusions}

To date limited information is available on crop residue and zinc ( $\mathrm{Zn})$ addition impacts on crop productivity, $\mathrm{Zn}$ uptake and soil physical properties, especially under highly calcareous and $\mathrm{Zn}$ deficient soils. The highest yield in both crops was recorded in the treatment receiving $10 \mathrm{~kg} \mathrm{Zn/ha}$ as starter dose along with $100 \%$ straw produced by each crop. The treatment receiving $5 \mathrm{~kg} \mathrm{Zn} / \mathrm{ha}+100 \%$ straw produced by each crop was the next promising treatment in enhancing the crop yield. The treatment with $100 \% \mathrm{CR}$ $+10 \mathrm{~kg} \mathrm{Zn} / \mathrm{ha}$ had the highest level of mean weight diameter (MWD) and water holding capacity (WHC), whereas it resulted into the lowest bulk density (BD). Increasing levels of $\mathrm{Zn}$ also influenced the MWD of water stable aggregates, $\mathrm{BD}$ and $\mathrm{WHC}$ positively. The correlations of WHC and MWD of water stable aggregates with different plant parameters were positive and highly significant, i.e. higher the WHC and MWD of water stable aggregates higher the crop yield and $\mathrm{Zn}$ utilization by crops. Thus, long-term application of crop residues along with $\mathrm{Zn}$ increased grain yield and soil physical properties under rice-wheat cropping system in calcareous soil.

\section{Acknowledgements}

The authors are highly thankful to the Chairman, Department of Soil Science, RAU, Pusa and Head, Indian Agricultural Research Institute Regional Station, Pusa, Samastipur, Bihar (India) for providing the laboratory facilities during this investigation. 


\section{References}

Bandyopadhyay, P.K., Saha, S., Mani, P.K., Mandal, B. 2010. Effect of organic inputs on aggregate associated organic carbon concentration under longterm rice-wheat cropping system. Geoderma. 154, 379-386.

Ghildyal, B.P., Gupta, R.P. 1991. Effect of application of crop residue, FYM and gypsum on water stable aggregates in different soils, soil structure problems and management. In: Soil Structure: Problems and Management. ICAR, Krishi Bhawan, New Delhi, India, 22p.

Jackson, M.L. 1958. Soil Chemical Analysis. Prentice Hall Inc., Englewood Cliffs, N. J., 485p.

Kumari, R. 2003. Zinc management through long term crop residues incorporation in rice-wheat system under Calciorthents. M.Sc. Thesis. Department of Soil Science, R.A.U., Pusa, Bihar, India.

Kumar, S. 2006. Influence of green manuring on chemistry of native zinc in calcareous soil under rice-wheat system Ph.D. Thesis. Department of Soil Science, R.A.U., Pusa, Bihar, India.

Mohammad, W., Shah, S.M., Shehzadi, S., Shah, S.A. 2012. Effect of tillage, rotation and crop residues on wheat crop productivity, fertilizer nitrogen and water use efficiency and soil organic carbon status in dry area (rainfed) of north-west Pakistan. J. Soil Sci. Plant Nutri.12, 715-727.

Neelam, Aggarwal, A., Gaur, A., Bhalla, E., Gupta, S.R. 2010. Soil aggregate carbon and diversity of mycorrhiza as affected by tillage practices in a rice-wheat cropping system in Northern India. Int. J. Ecol. Environ. Sci. 36, 233-243.

Pandey, A.K. 2012. Long term effect of organic and inorganic fertilizers on the distribution and transformation of $\mathrm{S}, \mathrm{Zn}$ and Boron in calcareous soil. Ph.D. Thesis. Department of Soil Science, RAU, Pusa, Bihar, India, 200.
Prasad, R.K.; Kumar, V., Mandal, K., Kumar, R. 2009. Long term application of zinc and crop residues on yield and uptake of micronutrients in transplanted rice under rice-wheat cropping system in calciorthents. Environ. Ecol. 27, 1440-1443.

Prasad, S.S., Sinha, S.K., Nanda, K.K., Ram, H. 2010. Effect of soil amendments on physico-chemical properties of salt-affected soils and yield attributing characters in rice-wheat cropping system. Environ. Ecol. 28, 592-597.

Rashid, A., Ryan, J. 2008. Micronutrient constraints to crop production in the Near East: Potential significance and management strategies. In: Micronutrient Deficiencies in Global Crop Production ed: Alloway, B.J. Springer Netherlands pp149-180.

Rathod, D.D., Meena, N.C., Patel K.P. 2012. Evaluation of different zinc-enriched organics as source of zinc under wheat-maize (fodder) cropping sequence on zinc deficient Typic Haplustepts. J. Ind. Soc. Soil Sci. 60, 50-55.

Sakal, R., Singh, A.P. 1979. Zinc hunger in Kharif crop grown on calcareous soil of North Bihar. Indian Farming. 28, 3-5.

Shivay, Y.S., Kumar, D., Prasad, R. 2008. Relative efficiency of Zinc sulphate and Zinc oxide coated urea in rice-wheat cropping system. Commun. Soil Sci. Plant Analysis. 39, 1154-1167.

Sirohi, G., Upadhyay, A., Srivastava P. S., Srivastava, S. 2015. PGPR mediated Zinc biofertilization of soil and its impact on growth and productivity of wheat. J. Soil Sci. Plant Nutr. 15, 202-216.

Wang, Q., Huang, Q., Zhang, Li., Zhang, JianChao., Shen, Q., Ran, Wei. 2012. The effects of compost in a rice-wheat cropping system on aggregate size, carbon and nitrogen content of the size-density fraction and chemical composition of soil organic matter, as shown by 13C CP NMR spectroscopy. Soil Use Management. 28, 337-346. 
Walia, M.K., Walia, S.S., Dhaliwal, S.S. 2010. Longterm effect of integrated nutrient management of properties of typic ustochrept after 23 cycles of an irrigated rice (Oryza sativa L.)-wheat (Triticum aestivum L.) system. J. Sustain. Agri. 34, 724-743.
Yoder, R. E. 1936. A direct method of aggregate analysis of soils and a study of the physical nature of erosion losses. J. Am. Soc. Agron. 28, 337-351. 